\title{
Response of Integrated Nutrient Management on Growth and Yield of Pearlmillet [Pennisetum glaucum (L.) R. Br. emend. Stuntz.]-Wheat (Triticum aestivum L.) Cropping System
}

\author{
Amit Kumar*, Mukesh Kumar and Naresh Kumar \\ Department of Agronomy, CCS Haryana Agricultural University, Hisar-125004, India \\ *Corresponding author
}

\section{A B S T R A C T}

A field experiment was undertaken to study the Response of Integrated Nutrients Management on Growth and Yield of Pearlmillet [Pennisetum glaucum (L.) R. Br. emend. Stuntz.]-Wheat (Triticum aestivum L.) cropping system. The investigation was carried out at Research Farm of Department of Agronomy CCS Haryana Agricultural University,

\section{Keywords}

Pearlmillet-Wheat, Cropping system, INM, Growth, Grain yield.

\section{Article Info}

Accepted:

19 July 2017

Available Online:

10 September 2017
Hisar during 2009-10 consisting of 12 treatment combination viz., $\mathrm{T}_{1}$ - control (no fertilizer): $\mathrm{T}_{2}-50 \%$ recommended NPK to pearlmillet and wheat: $\mathrm{T}_{3}-50 \%$ recommended NPK to pearlmillet and $100 \%$ recommended NPK to wheat; $\mathrm{T}_{4}-75 \%$ recommended NPK to pearlmillet and wheat; $\mathrm{T}_{5}-100 \%$ recommended NPK to pearlmillet and wheat; $\mathrm{T}_{6}-50 \%$ $\mathrm{NPK}+50 \% \mathrm{~N}$ (farmyard manure) to pearlmillet and $100 \%$ recommended NPK to wheat; $\mathrm{T}_{7}-75 \% \mathrm{NPK}+25 \% \mathrm{~N}$ (farmyard manure) to pearlmillet and $75 \%$ recommended NPK to wheat; $\mathrm{T}_{8}-50 \% \mathrm{NPK}+50 \% \mathrm{~N}$ (wheat straw) to pearlmillet and $100 \%$ recommended NPK to wheat; $\mathrm{T}_{9}-75 \% \mathrm{NPK}+25 \% \mathrm{~N}$ (wheat straw) to pearlmillet and $75 \%$ recommended NPK to wheat; $\mathrm{T}_{10}-50 \% \mathrm{NPK}+50 \% \mathrm{~N}$ (Sesbania spp.) to pearlmillet and $100 \%$ recommended NPK to wheat; $\mathrm{T}_{11}-75 \% \mathrm{NPK}+25 \% \mathrm{~N}$ (Sesbania $\mathrm{spp}$.) to pearlmillet and $75 \%$ recommended NPK to wheat and $\mathrm{T}_{12}$ - farmers' practice laid out in randomized block design. Results of the experiment revealed that plant height and dry matter accumulation was maximum in Treatment $\mathrm{T}_{6}$ which is significantly higher than inorganic treatments $\mathrm{T}_{1}$, $\mathrm{T}_{2}$ and $\mathrm{T}_{3}$ in pearlmillet and wheat but statistically at par with integrated treatments $\mathrm{T}_{5}$ and $\mathrm{T}_{10}$ in wheat and $\mathrm{T}_{5}$ and $\mathrm{T}_{11}$ in pearlmillet. Similarly, treatment $\mathrm{T}_{6}$ recorded highest grain and stover/straw yield of pearlmillet and wheat, which is statistically at par with $\mathrm{T}_{5}$ and $\mathrm{T}_{10}$ in wheat and $T_{5}$ and $T_{11}$ in pearlmillet but significantly superior to all other treatments in both the crops.

\section{Introduction}

Fertilizer (nutrient) is the key element that can be effectively managed to get desired use efficiency under a given situation. Higher food production needs higher amount of plant nutrients. Without careful management, manures can cause yield loss and lower crop quality as a result of both under and over fertilization. To avoid wastage of resources and to minimize the environmental damage there is a need to develop and demonstrate balanced use of organic/inorganic fertilizers. This will not only improve the crop production in sustainable way but also economise the crop production. 
As no single source is capable of supplying the balanced amount of nutrients, integrated use of all sources is a must to supply balanced nutrients to plants (Hedge and Babu, 2004). Pearlmillet [Pennisetum glaucum (L.) R. Br. emend. Stuntz.]-wheat (Triticum aestivum L.) is one of the important cropping systems of the country and spreads over (i) arid eco-region comprising, western plains, Kachh and parts of Kathiawar Peninsula having desert and saline soils representing Gujarat, Rajasthan and Haryana; (ii) semi-arid eco-region comprising northern plains of Haryana, western Uttar Pradesh and central high lands of Rajasthan with alluvium derived soils.

During last five decades, the food grain production increased by five folds from a low of 50.82 $\mathrm{mt}$ in 1950-51 to $252.22 \mathrm{mt}$ in 201516 and consumption of fertilizer $(\mathrm{N}+\mathrm{P}+\mathrm{K})$ has increased from 0.07 to $26.76 \mathrm{mt}$ (in nutrient terms) over the same period. A consumption of $26.76 \mathrm{mt}$ of nutrients comprising $17.37 \mathrm{mt}$ of nitrogen, $6.98 \mathrm{mt}$ of phosphorus and $2.4 \mathrm{mt}$ of potash. Consumption of fertilizers (all nutrients) per hectare increased from $1.0 \mathrm{~kg}$ to $150.5 \mathrm{~kg}$ in 2014-15 (Anonymous, 2016). Long term studies being carried out at several locations on different cropping systems indicated that application of all the needed nutrients through chemical fertilizers has deleterious effect on soil health, leading to unsustainable yields (Swarup, 2002 and Behra et al., 2007). This further has led to aggravated micro-nutrient deficiency in soil system. Since, the nutrient turnover in soilplant system is considerably high under intensive cropping system. So, neither the chemical fertilizers nor the organic/biological sources alone can achieve production sustainability. Even with the so called balance use of NPK fertilizers in long term studies, higher yield levels could not be maintained for years because of emergence of secondary and micro-nutrient deficiency and deterioration in the soil physical environment Whereas, organic manure alone or in combination with inorganic fertilizers is known to have favorable effect on soil environment and correct marginal deficiency of secondary and micro-nutrients and enhance efficiency of applied nutrients. Therefore, there is need to improve nutrient supply system for sustainable production of this very important cropping system of India.

\section{Materials and Methods}

The field experiment was carried out in permanent laid out research plots in Agronomy Research Area at CCS Haryana Agricultural University, Hisar during 200910. The soil of experiment site was sandy loam in texture. The experiment was laid out in randomized block design with 12 treatments combinations replicated four times. The treatments were: $\mathrm{T}_{1}-$ control (no fertilizer): $\mathrm{T}_{2}-, 50 \%$ recommended NPK to pearlmillet and wheat: $\mathrm{T}_{3}-50 \%$ recommended NPK to pearlmillet and $100 \%$ recommended NPK to wheat; $\mathrm{T}_{4}-75 \%$ recommended NPK to pearlmillet and wheat; $\mathrm{T}_{5}-100 \%$ recommended NPK to pearlmillet and wheat; $\mathrm{T}_{6}-50 \% \mathrm{NPK}+50 \% \mathrm{~N}$ (farmyard manure) to pearlmillet and $100 \%$ recommended NPK to wheat; $\mathrm{T}_{7}-75 \%$ NPK $+25 \% \mathrm{~N}$ (farmyard manure) to pearlmillet and $75 \%$ recommended NPK to wheat; $\mathrm{T}_{8}-$ $50 \% \mathrm{NPK}+50 \% \mathrm{~N}$ (wheat straw) to pearlmillet and $100 \%$ recommended NPK to wheat; $\mathrm{T}_{9}-75 \% \mathrm{NPK}+25 \% \mathrm{~N}$ (wheat straw) to pearlmillet and $75 \%$ recommended NPK to wheat; $\mathrm{T}_{10}-50 \% \mathrm{NPK}+50 \% \mathrm{~N}$ (Sesbania spp.) to pearlmillet and $100 \%$ recommended NPK to wheat; $\mathrm{T}_{11}-75 \% \mathrm{NPK}+25 \% \mathrm{~N}$ (Sesbania spp.) to pearlmillet and $75 \%$ recommended NPK to wheat and $\mathrm{T}_{12}$ farmers' practice. The recommended levels of $\mathrm{N}$ and $\mathrm{P}$ were 125 and $62.5 \mathrm{~kg} / \mathrm{ha}$ for pearlmillet and 150 and $60 \mathrm{~kg} / \mathrm{ha}$ wheat. The farmers' practice based on state average was 
$116 \mathrm{~kg} / \mathrm{ha} \mathrm{N}$ for pearlmillet. In wheat the farmers' practice based on state average was $138.75 \mathrm{~kg} / \mathrm{ha}$ for $\mathrm{N}$ and $54.75 \mathrm{~kg} / \mathrm{ha}$ for $\mathrm{P}$. The pearlmillet variety used was HHB-197 with 5 $\mathrm{kg} / \mathrm{ha}$ seed keeping intra row spacing of 10 $\mathrm{cm}$ and inter row spacing $45 \mathrm{~cm}$. In wheat variety $\mathrm{PBW}-502$ was sown with $100 \mathrm{~kg} / \mathrm{ha}$ seed keeping inter row spacing of $20 \mathrm{~cm}$. Pearlmillet was sown on June 21, 2009 and was harvested on September 6, 2009. Similarly, wheat was sown on November 2, 2009 and was harvested on April 11, 2010. The $\mathrm{N}$ content in different organic materials was determined and the amount of these materials required for substituting a specified amount of $\mathrm{N}$ as per the treatment was calculated.

The organic sources of nutrients viz., FYM, wheat straw and green manure were incorporated in soil 40, 43 and 36 days, respectively, before sowing pearmillet crop. The recommended $\mathrm{N}$ and $\mathrm{P}$ were applied through urea and DAP, respectively. Three post sowing irrigations were applied in pearlmillet. Similarly in wheat four irrigations were applied. Recommended package of practices were followed in both the crops for other agronomic operations. The grain and stover/straw yield was recorded after harvesting the crop.

\section{Results and Discussion}

Growth and development is a physiological phenomenon of plant life. The rate and amount of growth has a very considerable effect on ultimate yield of plant. The yield of any crop species depends on the source and sinks relationship and on different components of sink itself viz., effective tillers, length of earhead, 1000-grain weight etc. Source components may be plant populations, plant height, total tillers and dry matter accumulation of plants before anthesis.

\section{Effect of different treatments on Pearlmillet}

The results of the study (Table 1) revealed that growth characters like plant height, total tillers/plant and dry matter accumulation at harvest were highest in treatment $\mathrm{T}_{6}(50 \%$ RD-NPK $+50 \% \mathrm{~N}$ through FYM in pearlmillet and $100 \%$ RD-NPK in wheat). Treatment $\mathrm{T}_{6}$ recorded $49 \%$ taller plants over control. Treatment $\mathrm{T}_{6}$ recorded $11 \%$ higher total tillers over treatment $\mathrm{T}_{12}$ (farmers' practice). Dry matter in treatment $\mathrm{T}_{6}$ was also $7 \%$ higher over treatment $\mathrm{T}_{12}$. Dry matter accumulation at harvest increased significantly with increasing dose of inorganic fertilizers. Treatment $\mathrm{T}_{5}$ (100\% recommended NPK to pearlmillet and wheat) recorded 115 , 53, 37 and $18 \%$ higher dry matter accumulation over treatments $T_{1}, T_{2}, T_{3}$ and $\mathrm{T}_{4}$, respectively.

Supplying full dose of recommended nutrients through inorganic sources provide these in readily available form to the crop. This is in agreement with the findings of Kundu et al., (2006) and Dahiya et al., (2008), who also reported higher response to inorganic sources than to organic sources. The results of the study revealed that treatment $\mathrm{T}_{6}$ recorded 258 and $22 \%$ highest $(3644 \mathrm{~kg} / \mathrm{ha})$ grain yield of pearlmillet over treatments $\mathrm{T}_{1}$ (control) and $\mathrm{T}_{12}$ (farmers' practice) and significantly better over rest of the other treatments except treatments $T_{5}$ and $T_{11}$. Similarly stover yield was also recorded highest in treatment $T_{6}$. Pronounced response obtained through the application of FYM in growth characters might be attributed primarily to the enriched supply of essential nutrients and enhanced availability of native phosphorus. The $\mathrm{CO}_{2}$ produced during the mineralization of organic matter plays important role in the solubilization of native phosphorus. FYM might also have resulted in the formation of phospho-humic complexes which are more 
easily absorbed by plants or the isomorphous replacement of phosphate ions by humate ions and coating of sesquioxide particles by humus to form a protective cover which reduces the phosphate fixing capacity of soil and thus increases its availability.

Table.1 Effect of different treatments on growth parameters and productivity of pearlmillet

\begin{tabular}{|c|c|c|c|c|c|}
\hline Treatments & $\begin{array}{c}\text { Plant } \\
\text { height at } \\
\text { harvest } \\
\text { (cm) }\end{array}$ & $\begin{array}{c}\text { Effective } \\
\text { tillers/plant } \\
\text { at harvest }\end{array}$ & $\begin{array}{c}\text { Dry matter } \\
\text { accumulation at } \\
\text { physiological } \\
\text { maturity (g/plant) }\end{array}$ & $\begin{array}{c}\text { Grain } \\
\text { yield } \\
\text { (kg/ha) }\end{array}$ & $\begin{array}{c}\text { Stover yield } \\
\text { (kg/ha) }\end{array}$ \\
\hline $\mathbf{T}_{\mathbf{1}}$ & 153.3 & 2.80 & 52.2 & 1018 & 2862 \\
\hline $\mathbf{T}_{\mathbf{2}}$ & 199.8 & 3.03 & 73.3 & 2348 & 4637 \\
\hline $\mathbf{T}_{\mathbf{3}}$ & 211.5 & 3.23 & 82.0 & 2506 & 6515 \\
\hline $\mathbf{T}_{\mathbf{4}}$ & 216.4 & 3.53 & 95.5 & 2967 & 7402 \\
\hline $\mathbf{T}_{\mathbf{5}}$ & 223.5 & 4.08 & 112.3 & 3472 & 8538 \\
\hline $\mathbf{T}_{\mathbf{6}}$ & 225.0 & 4.18 & 114.9 & 3644 & 9025 \\
\hline $\mathbf{T}_{\mathbf{7}}$ & 222.9 & 4.04 & 11.9 & 3356 & 8272 \\
\hline $\mathbf{T}_{\mathbf{8}}$ & 214.7 & 3.34 & 82.6 & 2884 & 7070 \\
\hline $\mathbf{T}_{\mathbf{9}}$ & 218.8 & 3.75 & 102.4 & 3028 & 7508 \\
\hline $\mathbf{T}_{\mathbf{1 0}}$ & 222.3 & 3.85 & 108.2 & 3364 & 7935 \\
\hline $\mathbf{T}_{\mathbf{1}}$ & 224.3 & 4.11 & 113.2 & 3482 & 8602 \\
\hline $\mathbf{T}_{\mathbf{1 2}}$ & 220.3 & 3.78 & 107.2 & 2993 & 7596 \\
\hline $\mathbf{S E m} \mathbf{\pm}$ & $\mathbf{4 . 1 7}$ & $\mathbf{0 . 1 3}$ & $\mathbf{1 . 2 1}$ & $\mathbf{7 0 . 1}$ & $\mathbf{1 8 2 . 4}$ \\
\hline $\mathbf{C D}(\mathbf{P}=\mathbf{0 . 0 5})$ & $\mathbf{1 2 . 1}$ & $\mathbf{0 . 3 9}$ & $\mathbf{3 . 5 0}$ & $\mathbf{2 0 8 . 5}$ & $\mathbf{5 4 1 . 9}$ \\
\hline
\end{tabular}

Table.2 Effect of different treatments on growth parameters and productivity of wheat

\begin{tabular}{|c|c|c|c|c|c|c|}
\hline Treatments & $\begin{array}{c}\text { Plant } \\
\text { stand at } \\
\text { 20 DAS }\end{array}$ & $\begin{array}{c}\text { Plant } \\
\text { height at } \\
\text { harvest } \\
\text { (cm) }\end{array}$ & $\begin{array}{c}\text { Effective } \\
\text { tillers/ } \\
\text { meter row } \\
\text { length }\end{array}$ & $\begin{array}{c}\text { Dry matter } \\
\text { accumulation } \\
\text { at harvest } \\
\text { (g/plant) }\end{array}$ & $\begin{array}{c}\text { Grain } \\
\text { yield } \\
\text { (kg/ha) }\end{array}$ & $\begin{array}{c}\text { Straw } \\
\text { yield } \\
\text { (kg/ha) }\end{array}$ \\
\hline $\mathbf{T}_{\mathbf{1}}$ & 36.12 & 61.1 & 54.1 & 54.8 & 1106 & 1247 \\
\hline $\mathbf{T}_{\mathbf{2}}$ & 40.25 & 92.1 & 82.3 & 168.8 & 3812 & 4270 \\
\hline $\mathbf{T}_{\mathbf{3}}$ & 42.26 & 102.9 & 102.9 & 237.3 & 5418 & 6216 \\
\hline $\mathbf{T}_{\mathbf{4}}$ & 41.04 & 97.8 & 90.8 & 204.8 & 4716 & 5287 \\
\hline $\mathbf{T}_{\mathbf{5}}$ & 42.88 & 104.4 & 104.7 & 243.0 & 5738 & 6452 \\
\hline $\mathbf{T}_{\mathbf{6}}$ & 43.12 & 106.2 & 105.4 & 244.9 & 5922 & 6617 \\
\hline $\mathbf{T}_{\mathbf{7}}$ & 41.75 & 100.9 & 98.8 & 223.0 & 4933 & 5538 \\
\hline $\mathbf{T}_{\mathbf{8}}$ & 42.52 & 103.2 & 103.1 & 240.3 & 5564 & 6260 \\
\hline $\mathbf{T}_{\mathbf{9}}$ & 40.20 & 98.9 & 96.7 & 212.2 & 4772 & 5381 \\
\hline $\mathbf{T}_{\mathbf{1 0}}$ & 43.00 & 105.8 & 105.5 & 243.6 & 5767 & 6466 \\
\hline $\mathbf{T}_{\mathbf{1 1}}$ & 41.22 & 100.0 & 98.0 & 220.2 & 4784 & 5409 \\
\hline $\mathbf{T}_{\mathbf{1 2}}$ & 42.02 & 101.4 & 100.7 & 232.2 & 5256 & 6155 \\
\hline $\mathbf{S E m} \mathbf{\pm}$ & $\mathbf{2 . 1 1}$ & $\mathbf{0 . 8 4}$ & $\mathbf{1 . 4 0}$ & $\mathbf{0 . 6 7}$ & $\mathbf{7 3 . 1}$ & $\mathbf{7 8 . 4}$ \\
\hline $\mathbf{C D}(\mathbf{P}=\mathbf{0 . 0 5})$ & $\mathbf{N S}$ & $\mathbf{2 . 4 6}$ & $\mathbf{4 . 1 5}$ & $\mathbf{1 . 9 6}$ & $\mathbf{2 1 7 . 4}$ & $\mathbf{2 2 5 . 2}$ \\
\hline & & & & & & \\
\hline
\end{tabular}

\section{Effect of different treatments on wheat}

Plant stand was not affected by different treatments (Table 2). Maximum grain yield $\left(5922 \mathrm{~kg} / \mathrm{ha}^{\prime}\right.$ and straw yield $\left(6617 \mathrm{~kg} / \mathrm{ha}^{\prime}\right.$ was recorded in treatment $\mathrm{T}_{6}$, which is significantly higher than $\mathrm{T}_{1}, \mathrm{~T}_{2}, \mathrm{~T}_{3}, \mathrm{~T}_{4}, \mathrm{~T}_{7}, \mathrm{~T}_{8}$, $\mathrm{T}_{9}, \mathrm{~T}_{11}$ and $\mathrm{T}_{12}$ but statically at par with $\mathrm{T}_{5}$ and $\mathrm{T}_{11}$. Treatment $\mathrm{T}_{6}$ recorded 435 and $12 \%$ higher grain yield and 430 and $8 \%$ higher 
straw yield over control and farmers' practice, respectively, indicating that $50 \% \mathrm{~N}$ can be supplemented through FYM in pearlmilletwheat cropping system. The highest grain yield in treatment $\mathrm{T}_{6}$ is being supported by growth and yield contributing characters. Tallest plant was recorded in $\mathrm{T}_{6}$. Similarly, maximum no. of effective tillers/meter row length and dry matter accumulation was recorded in $\mathrm{T}_{6}$ which is statistically at par with $\mathrm{T}_{5}$ and $\mathrm{T}_{10}$ but significantly superior to rest of the treatments and 95 and $347 \%$ higher over control, respectively. The results are in confirmation to the findings of Katyal et al., (2002) and Jain and Poonia (2003).

Experiment concluded that the integrated nutrient management in pearlmillet-wheat cropping system have positive effect on growth parameters and ultimately on yield. Highest yield of both pearlmillet and wheat in pearlmilletwheat cropping system can be obtained with the application of $50 \%$ RD-NPK $+50 \% \mathrm{~N}$ through FYM to pearlmillet and $100 \%$ recommended dose of NPK to wheat.

\section{References}

Anonymous, 2016. http://eands.dacnet. nic.in/PDF/Glance-2016.pdf

Behra, U.K., Sharma, A.R. and Pandey, H.N. 2007. Sustaining productivity of wheatsoybean cropping system through integrated nutrient management practices on the vertisols of central India. Plant and Soil. 297(1/2): 185-
199.

Dahiya, D.S., Dahiya, S.S., Lathwal, O.P., Sharma, R. and Sheoran, R.S. 2008. Integrated nutrient management in wheat under rice-wheat cropping system. Haryana Journal of Agronomy. 24(1/2): 51-54.

Hegde, D.M., and Babu, S.N.S. 2004. Role of balanced fertilization in improving crop yield and quality. Fertiliser News. 49(12): 103-110.

Jain, N.K., and Poonia, B.L. 2003. Integrated nutrient management in pearlmillet (Pennisetum glaucum) and optimising fertilizer requirement in succeeding wheat (Triticum aestivum). Crop Research. 26: 62-66.

Katyal, V., Gangwar, B. and Gangwar, K.S. 2002. Yield trends and soil fertility changes in pearlmillet-wheat cropping system under long term integrated nutrient management. Annals of Agriculural Research (New Series). 23: 201-205.

Kundu, S., Kundu, A.L., Pal, S. and Mandal, N.N. 2006. Studies on crop yield and changes on soil properties as influenced by sustainable nutrient management in rice-wheat cropping system. Journal of Interacademicia. 10(1): 36-39.

Swarup, A., 2002. Lessons from long term fertilizer experiments in improving fertilizer use efficiency and crop yield. Fertilizers News. 47(2): 59-66, 71-73.

\section{How to cite this article:}

Amit Kumar, Mukesh Kumar and Naresh Kumar. 2017. Response of Integrated Nutrient Management on Growth and Yield of Pearlmillet [Pennisetum glaucum (L.) R. Br. emend. Stuntz.]-Wheat (Triticum aestivum L.) Cropping System. Int.J.Curr.Microbiol.App.Sci. 6(9): 1386-1390. doi: https://doi.org/10.20546/ijcmas.2017.609.168 